Hal. $252-261$

\title{
VARIABEL YANG MEMPENGARUHI KEPUASAN KERJA DAN TURNOVER INTENTION PEGAWAI DINAS PENDIDIKAN KABUPATEN PROBOLINGGO
}

\author{
Nurohma Afrianti \\ Fakultas Ekonomi dan Bisnis Universitas Jember \\ fathir14513@gmail.com \\ Purnamie Titisari \\ Fakultas Ekonomi dan Bisnis Universitas Jember \\ Handriyono \\ Fakultas Ekonomi dan Bisnis Universitas Jember
}

\begin{abstract}
This study aims to examine the effect of work stress, organizational climate, and employee engagement on work satisfaction and turnover intention of the staffs of Education Department of Probolinggo Regency. The research sample consists of 83 respondents. Data were analyzed using path analysis. Results of the research show that work stress, organizational climate, and employee engagement have direct effect and indirect effect through work satisfaction on turnover intention of the staffs of Education Department of Probolinggo Regency.
\end{abstract}

Keywords: Work Stress, Organizational Climate, Employee Engagement, Work Satisfaction, and Turnover Intention.

\begin{abstract}
Abstrak: Penelitian ini bertujuan untuk menganalisis pengaruh stres kerja, iklim organisasi, dan employee engagement terhadap kepuasan kerja dan turnover intention pada pegawai Dinas Pendidikan Kabupaten Probolinggo. Sampel penelitian terdiri dari 83 responden. Data dianalisis dengan menggunakan analisis jalur. Hasil penelitian membuktikan bahwa stres kerja, iklim organisasi, dan employee engagement berpengaruh terhadap turnover intention baik secara langsung maupun tidak langsung melalui kepuasan kerja pegawai di Dinas Pendidikan Kabupaten Probolinggo.
\end{abstract}

Kata Kunci: Stress Kerja, Iklim Organisasi, Employee Engagement, Kepuasan Kerja, dan Turnover Intention.

\section{Pendahuluan}

Sumber daya manusia merupakan faktor terpenting dalam setiap organisasi baik perusahaan swasta maupun institusi pemerintahan, karena bagaimanapun canggihnya teknologi yang digunakan tanpa didukung oleh manusia sebagai pelaksana kegiatan operasionalnya tidak akan mampu menghasilkan output yang sesuai dengan tingkat efisiensi yang diharapkan. Teori manajemen sumber daya manusia memberi petunjuk bahwa hal-hal yang harus diperhatikan dalam pemeliharaan hubungan tersebut menyangkut iklim organisasi, penanggulangan stres, motivasi, kepuasan kerja, sistem komunikasi, perubahan dan pengembangan 
organisasi serta meningkatkan mutu hidup dan kesejahteraan para karyawan atau pekerja (Bianca dan Susihono, 2012: 169).

Masalah stres kerja dalam kehidupan organisasi perusahaan menjadi gejala yang penting diamati sejak mulai timbulnya tuntutan untuk efisien di dalam pekerjaan. Menurut Robbins dan Judge (2013: 361) Stres dapat menjadi hambatan bagi pegawai untuk mencapai kepuasan kerja. Artinya stress kerja berpengaruh menurunkan tingkat kepuasan kerja. Wirawan (2007: 85) mendefinisikan iklim organisasi sebagai koleksi dan pola lingkungan yang menentukan munculnya motivasi serta berfokus pada persepsi-persepsi yang masuk akal atau dapat dinilai, sehingga mempunyai pengaruh langsung terhadap kinerja anggota organisasi. Semakin kondusif iklim organisasi semakin menunjang suasana kerja sehingga pegawai memperoleh kepuasan dalam bekerja

Hal tersebut dibuktikan pada beberapa penelitian terdahulu, di antaranya Fitria (2015), Mamewe (2015) dan penelitian Tadampali, dkk (2016). Penelitian Fitria (2015) yang dilakukan pada salah satu rumah sakit di Surabaya membuktikan bahwa stress kerja berpengaruh negatif signifikan pada kepuasan kerja, yang juga meningkatkan turnover intention perawat. penelitian Mamewe (2015) yang dilakukan di Kantor Badan Keuangan dan asset Daerah Kabupaten Sorong hasilnya meskipun tidak signifikan, stress kerja berpengaruh negatif pada kepuasan kerja, yang juga meningkatkan turnover intention pegawai. Penelitian Tadampali, dkk (2016) mengambil obyek penelitian pegawai PT Bank Sulawesi Tenggara. Ketiga penelitian tersebut membuktikan bahwa stress kerja, iklim organisasi berpengaruh positif pada kepuasan kerja pegawai, sehingga dapat menekan atau menurunkan tingkat turnover intention.

Turnover intention adalah derajat kecenderungan sikap yang dimiliki karyawan untuk mencari pekerjaan baru di tempat lain atau adanya rencana untuk meninggalkan perusahaan dalam masa yang telah ditentukan. Tingkat turnover yang tinggi akan menimbulkan dampak negatif bagi organisasi, diantaranya hilangnya sumber daya manusia yang berkualitas, peningkatan sumber daya manusia berupa biaya pelatihan yang sudah diinvestasikan pada karyawan yang keluar sampai biaya rekrutmen dan pelatihan kembali serta hilangnya nilai-nilai budaya kerja di perusahaan. Salah satu cara untuk menekan tingkat turnover intention tenaga kerja dengan meningkatkan keterikatan yang positif pada individu karyawan terhadap organisasi yang disebut employee engagement. 
Employee engagement merupakan gagasan multidimensi secara emosi, kognitif ataupun fisik (Rachman dan Dewanto, 2006). Employee engagement juga merupakan salah satu dari faktor human capital yang akan membawa pada keberhasilan jika dapat dikelola dengan baik secara konsisten. Schieman (2011: 30) mengartikan engagement (keterikatan) sebagai energi atau motivasi dari karyawan untuk membantu organisasi dalam upaya mencapai tujuan yang telah ditetapkan.

Fenomena di atas tidak saja terjadi pada perusahaan swasta, tetapi juga pada institusi pemerintahan. Reformasi pemerintahan yang terjadi di Indonesia telah mengakibatkan terjadinya pergeseran paradigma penyelenggara-an pemerintahan dari paradigma senteralistis ke arah desentralisasi yang ditandai dengan pemberian otonomi yang luas dan nyata kepada daerah dengan berlaku-nya Undang-Undang Nomor 32 Tahun 2004 tentang Pemerintahan Daerah.

Berdasarkan Undang-Undang tersebut dimana pemerintah memberikan kepada daerah otonomi yang luas, nyata, dan bertanggung jawab, sehingga kondisi ini mengubah konfigurasi penyelenggaraan manajemen pemerintahan di daerah. Pemberian otonomi daerah ini diarahkan untuk mempercepat terwujudnya kesejahteraan masyarakat melalui peningkatan pelayanan, pemberdayaan (empowering), dan peran serta masyarakat dalam menata pembangunan daerah.

Dinas Pendidikan adalah institusi pelayanan pendidikan di bawah naungan Pemerintah Kabupaten Probolinggo, Propinsi Jawa Timur yang beralamat di Jalan Raya Panglima Sudirman nomor 128, Kraksaan dengan jumlah pegawai 105 (seratus lima) orang. Dinas Pendidikan Kabupaten Probolinggo memiliki visi terselenggaranya pendidikan yang berkualitas dan ber-karakter. Misi Dinas Pendidikan Kabupaten Probolinggo antara lain meningkatkan ketersediaan dan keterjangkauan layanan pendidikan yang bermutu, meningkatkan mutu dan relevansi layanan pendidikan, meningkatkan tata kelola dan transparansi serta akuntabel layanan pendidikan. Dinas Pendidikan Kabupaten Probolinggo sebagai institusi penyelenggara layanan pendidikan bertanggung jawab kepada masyarakat untuk membentuk sumber daya manusia yang berkualitas. Pemenuhan tanggung jawab tersebut tentunya akan dapat terwujud apabila institusi penyedia layanan pendidikan juga memilih kualitas yang baik. Hal tersebut dapat diwujudkan apabila Dinas Pendidikan Kabupaten Probolinggo memiliki ketenaga kerjaan yang sehat.

Pada kenyataannya, banyaknya perubahan kebijakan seperti perubahan Peraturan Menteri Dalam Negeri tentang sistem kerja berdampak pada perubahan 
aturan dan struktur organisasi. Perubahan Undang-Undang tentang dunia pendidikan juga berdampak pada perubahan strategi pencapaian visi pendidikan yang telah ditetapkan. Perubahan-perubahan tersebut mempengaruhi iklim organisasi dalam Dinas Pendidikan Kabupaten Probolinggo. Iklim organisasi tersebut kurang mendukung untuk terwujudnya ketenaga kerjaan yang sehat dan berkualitas, sehingga hal tersebut dapat mempengaruhi perilaku karyawan yang dapat memunculkan potensi stres dan pada akhirnya berdampak pada kepuasan kerja pegawai.

Angka turnover pegawai Dinas Pendidikan Kabupaten Probolinggo tergolong tinggi. Menurut Kepala Dinas Pendidikan Kabupaten Probolinggo, sampai dengan akhir tahun 2016 turnover pegawai Dinas Pendidikan Kabupaten Probolinggo pada kisaran $8 \%$ sampai $10 \%$, sehingga rekrutmen dan training sangat sering dan harus dilakukan untuk mengganti posisi atau jabatan yang ditinggalkan oleh pegawai sebelumnya. Turnover pegawai kebanyakan terjadi pada kalangan pegawai yang belum berstatus PNS (Pegawai Negeri Sipil). Turnover di kalangan PNS jarang terjadi, hal ini terjadi karena adanya pemikiran di masyarakat bahwa PNS memiliki masa depan yang baik setelah mereka pensiun.

Salah satu upaya meminimalkan angka turnover di lingkungan Dinas Pendidikan Kabupaten Probolinggo adalah dengan memberikan bantuan dana pendidikan bagi pegawai berprestasi untuk melanjutkan ke jenjang pendidikan yang lebih tinggi. Namun bantuan dana pendidikan sangat terbatas baik jumlahnya maupun plafon nominalnya. Konsekuensi bagi pegawai yang menerima bantuan dana pendidikan tersebut yaitu pegawai penerima bantuan dana pendidikan terikat masa kerja, dan dikenakan sangsi pengembalian bantuan apabila terjadi di kemudian hari pegawai tersebut mengingkari kesepakatan. Cara ini merupakan upaya Dinas Pendidikan Kabupaten Probolinggo melaksanakan employee engagement untuk pegawai Dinas Pendidikan Kabupaten Probolinggo yang berpotensi. Tetapi upaya ini ternyata tidak nampak mempengaruhi angka turnover pegawai. Hal tersebut karena sasarannya adalah pegawai yang sudah berstatus PNS, sedangkan turnover intention umumnya terjadi di kalangan pegawai yang masih belum berstatus PNS, baik tenaga honorer maupun pegawai dengan status Calon PNS.

Studi mengenai turnover intention pegawai pemerintahan khususnya Dinas Pendidikan Kabupaten Probolinggo adalah hal yang penting dilakukan untuk memprediksi seberapa besar pengaruh stres kerja, iklim organisasi, dan employee 
engagement terhadap kepuasan kerja, di mana selanjutnya kepuasan kerja pegawai akan menekan angka turnover intention pegawai.

Tujuan penelitian mengenai turnover intention pegawai Dinas Pendidikan Kabupaten Probolinggo adalah untuk : (1) Menganalisis pengaruh stres kerja, iklim organisasi, dan employee engagement terhadap kepuasan kerja pegawai Dinas Pendidikan Kabupaten Probolinggo; (2) Menganalisis pengaruh stres kerja, iklim organisasi, dan employee engagement terhadap turnover intention pegawai Dinas Pendidikan Kabupaten Probolinggo; (3) Menganalisis pengaruh kepuasan kerja terhadap turnover intention pegawai Dinas Pendidikan Kabupaten Probolinggo.

\section{Metodologi}

Penelitian ini menggunakan pendekatan causal research design, yaitu suatu penelitian yang bertujuan menjelaskan hubungan kausal antar variabel melalui pengujian hipotesis. Menurut Sugiyono (2013: 37), tujuan utama causal research adalah untuk membuktikan hubungan sebab akibat antar variabel dan membandingkan pengaruh beberapa variabel terhadap suatu variabel sehingga dapat diketahui variabel yang dominan pengaruhnya terhadap suatu variabel. Penggalian data penelitian ini menggunakan teknik survei yang dilakukan dengan kuesioner dan skala pengukuran variabel adalah skala Likert.

\section{Populasi dan Sampel}

Dalam penelitian ini yang menjadi populasi adalah seluruh pegawai Dinas Pendidikan Kabupaten Probolinggo, yang bukan merupakan tenaga pendidik, berjumlah 105 orang. Penentuan ukuran sampel menggunakan rumus Slovin yang memiliki fleksibilitas untuk jumlah populasi dan tingkat signifikan yang diharapkan. Jumlah populasi penelitian ini ada 105 orang, dengan jumlah populasi tersebut, dan derajat kepercayaan $95 \%$, maka ukuran sampel ditentukan batas kesalahan 5\%, sehingga jumlah sampel adalah sebesar 83 orang.

\section{Alat Analisis}

Perhitungan analisis jalur menjelaskan tentang Stres Kerja $\left(X_{1}\right)$, Iklim Organisasi $\left(\mathrm{X}_{2}\right)$ dan Employee Engagement $\left(\mathrm{X}_{3}\right)$, baik secara langsung maupun tidak langsung terhadap Turnover Intention pegawai $(Y)$ melalui variabel intervening yakni Kepuasan Kerja (Z). Kaidah pengujian signifikan dalam pengujian SPSS (Ridwan dan Kuncoro, 2007:117) adalah: 
a. jika nilai probabilitas 0,05 lebih kecil atau sama dengan nilai probabilitas Sig atau $[0,05 \leq \mathrm{Sig}$ ], maka Ho diterima dan Ha ditolak, artinya tidak signifikan.

b. Jika nilai probabilitas 0,05 lebih besar atau sama dengan nilai probabilitas Sig atau $[0,05 \leq S i g]$, maka Ho ditolak dan Ha diterima, artinya signifikan

Sebelum menghitung jalur, maka sebelumnya masing-masing jalur harus diuji signifikansinya. Apabila masing-masing koefisien jalur terbukti signifikansi, maka untuk proses perhitungannya adalah sebagai berikut:

a. Identifikasi sub-struktur dan persamaan.

Keterangan:

$$
\begin{aligned}
& Z=\beta X_{1 Z} X_{1}+\beta X_{2 Z} X_{2}+\beta X_{3 Z} X_{3}+e_{i} \\
& Y=\beta X_{1} Y X_{1}+\beta X_{2 Y} X_{2}+\beta X_{3} Y X_{3}+\beta Z Y Z+e_{i}
\end{aligned}
$$

$\mathrm{Z} \quad=$ Kepuasan Kerja pegawai

$\mathrm{Y} \quad=$ Turnover Intention pegawai

$\beta=$ Koefisien jalur

$\mathrm{X}_{1}=$ Stres Kerja

$\mathrm{X}_{2}=$ Iklim Organisasi

$X_{3}=$ Employee Engagement

$\mathrm{e}_{\mathrm{i}} \quad=$ estimasi penyimpangan (error)

b. Identifikasi persamaan pengaruh tidak langsung.

Keterangan:

$$
Y=\beta \times 1 Z . \beta \times 1 Y X_{1}+\beta \times 2 Z . \beta \times 2 Y X_{2}+\beta \times 3 Z . \beta \times 3 Y X_{3}+\beta Z Y Z+e_{i}
$$

$\mathrm{Z}=$ Kepuasan Kerja pegawai

$\mathrm{Y} \quad=$ Turnover Intention pegawai

$\beta=$ Koefisien jalur

$X_{1}=$ Stres Kerja

$\mathrm{X}_{2}=$ Iklim Organisasi

$\mathrm{X}_{3}=$ Employee Engagement

$\mathrm{e}_{\mathrm{i}} \quad$ = estimasi penyimpangan (error)

c. Identifikasi pengaruh total.

Pengaruh total dihitung dari pengaruh langsung ditambah dengan pengaruh tidak langsung. Menghitung Pengaruh total (Total Effect atau TE):

Total Effect $=$ Direct Effect + Indirect Effect $\mathrm{TE}=\mathrm{DE}+\mathrm{IE}$

Apabila terdapat jalur yang tidak signifikansi maka dilakukan trimming theory yaitu dengan menghitung jalur yang tidak signifikan. Dalam penelitian hasil dari uji hipotesis adalah signifikan, sehingga tidak diperlukan trimming. 


\section{Hasil Dan Pembahasan}

Berdasarkan hasil analisis jalur yang dilakukan dengan software SPSS 20 for windows diperoleh koefisian dari masing-masing jalur pengaruh langsung yang disajikan dalam tabel berikut ini.

Tabel 1: Nilai Koefisien Jalur

\begin{tabular}{|c|c|c|c|c|c|}
\hline No. & Variabel Bebas & Variabel Terikat & $\begin{array}{c}\text { Beta } \\
(\beta)\end{array}$ & $\begin{array}{c}\rho- \\
\text { value }\end{array}$ & Keterangan \\
\hline 1. & Stres Kerja $\left(\mathrm{X}_{1}\right)$ & $\begin{array}{c}\text { Kepuasan Kerja } \\
(\mathrm{Z})\end{array}$ & 0,400 & 0,000 & Signifikan \\
\hline 2. & Iklim Organisasi $\left(\mathrm{X}_{2}\right)$ & $\begin{array}{c}\text { Kepuasan Kerja } \\
(Z)\end{array}$ & 0,512 & 0,000 & Signifikan \\
\hline 3. & $\begin{array}{c}\text { Employee Engagement } \\
\left(\mathrm{X}_{3}\right)\end{array}$ & $\begin{array}{c}\text { Kepuasan Kerja } \\
(\mathrm{Z})\end{array}$ & 0,087 & 0,032 & Signifikan \\
\hline 4. & Stres Kerja $\left(\mathrm{X}_{1}\right)$ & $\begin{array}{c}\text { Turnover Intention } \\
(\mathrm{Y})\end{array}$ & 0,218 & 0,045 & Signifikan \\
\hline 5. & Iklim Organisasi $\left(\mathrm{X}_{2}\right)$ & $\begin{array}{l}\text { Turnover Intention } \\
(\mathrm{Y})\end{array}$ & 0,413 & 0,001 & Signifikan \\
\hline 6. & $\begin{array}{l}\text { Employee Engagement } \\
\left(\mathrm{X}_{3}\right)\end{array}$ & $\begin{array}{l}\text { Turnover Intention } \\
(\mathrm{Y})\end{array}$ & 0,148 & 0,001 & Signifikan \\
\hline 7. & Kepuasan Kerja (Z) & $\begin{array}{l}\text { Turnover Intention } \\
(\mathrm{Y})\end{array}$ & 0,237 & 0,042 & Signifikan \\
\hline
\end{tabular}

Sumber: data diolah

Berdasarkan Tabel 1 dapat dilihat pada kolom beta $(\beta)$, bahwa nilai yang terbesar adalah koefisien dari variabel Iklim Organisasi, artinya Iklim Organisasi menuju Kepuasan Kerja merupakan jalur pengaruh paling kuat dengan koefisien jalur pengaruh langsung 0,512. Berikutnya dengan koefisien jalur 0,413 merupakan jalur pengaruh langsung Iklim Organisasi menuju Turnover Intention.

Pengujian jalur pengaruh langsung menghasilkan model persamaan berikut:

$$
\begin{gathered}
Z=3,689+0,400 X_{1}+0,512 X_{2}+0,087 X_{3}+\varepsilon i \\
Y=3,450+0,218 X_{1}+0,413 X_{2}+0,148 X_{3}+0,237 Z+\varepsilon i
\end{gathered}
$$

$\underline{\text { Uji Hipotesis }}$

Kriteria uji signifikansi diperoleh dari perbandingan antara nilai signifikan hasil analisis dengan level of significant ( $\alpha$ ) ketetapan yaitu $5 \%$ atau 0,05 . Apabila signifikansi < 0,05 maka Ho ditolak dan Ha diterima yang artinya bahwa variabel bebas memiliki pengaruh terhadap variabel terikatnya. Apabila signifikansi $\geq 0,05$ maka Ho diterima dan Ha ditolak yang artinya bahwa variabel bebas tidak memiliki pengaruh terhadap variabel berikutnya. 
Tabel 2: Hasil Uji Hipotesis

\begin{tabular}{ccccc}
\hline No. & Hipotesis & $\begin{array}{c}\text { Beta } \\
(\boldsymbol{\beta})\end{array}$ & Sig. & Keterangan \\
\hline 1. & $\left(\mathrm{X}_{1}\right) \rightarrow$ Kepuasan Kerja $(\mathrm{Z})$ & 0,400 & 0,000 & H0 ditolak, Signifikan \\
2. & $\left(\mathrm{X}_{2}\right) \rightarrow$ Kepuasan Kerja $(\mathrm{Z})$ & 0,512 & 0,000 & H0 ditolak, Signifikan \\
3. & $\left(\mathrm{X}_{3}\right) \rightarrow$ Kepuasan Kerja $(\mathrm{Z})$ & 0,087 & 0,032 & H0 ditolak, Signifikan \\
4. & $\left(\mathrm{X}_{1}\right) \rightarrow$ Turnover Intention $(\mathrm{Y})$ & 0,218 & 0,045 & H0 ditolak, Signifikan \\
5. & $\left(\mathrm{X}_{2}\right) \rightarrow$ Turnover Intention $(\mathrm{Y})$ & 0,413 & 0,001 & H0 ditolak, Signifikan \\
6. & $\left(\mathrm{X}_{3}\right) \rightarrow$ Turnover Intention $(\mathrm{Y})$ & 0,148 & 0,001 & H0 ditolak, Signifikan \\
7. & $(\mathrm{Z}) \rightarrow$ Turnover Intention $(\mathrm{Y})$ & 0,237 & 0,042 & H0 ditolak, Signifikan \\
\hline
\end{tabular}

Sumber: data diolah

Berdasarkan tabel 2 di atas, hasil pengujian hipotesis menunjukkan bahwa variabel stres kerja, iklim organisasi, dan employe engagement berpengaruh signifikan terhadap variabel turnover intention maupun terhadap variabel interveningnya yaitu kepuasan kerja. Hal ini dikarenakan hasil uji hipotesis menunjukkan nilai siginifikasinya kurang dari 0.05 (5\%).

\section{Menghitung Jalur}

Setelah pengujian hipotesis penelitian, langkah selanjutnya adalah menghitung koefisien pengaruh antar variabel-variabel dalam model penelitian tersebut. Berdasarkan Tabel 2, tidak terdapat jalur yang koefisiennya tidak signifikan sehingga tidak diperlukan tindakan trimming. Hasil pengaruh langsung, pengaruh tidak langsung dan pengaruh total seperti table dibawah ini :

Tabel 3. Hasil Pengaruh Total

\begin{tabular}{cccccc}
\hline No. & Jalur & $\begin{array}{c}\text { Pengaruh } \\
\text { Langsung }\end{array}$ & Jalur & $\begin{array}{c}\text { Pengaruh Tidak } \\
\text { Langsung }\end{array}$ & $\begin{array}{c}\text { Pengaruh } \\
\text { Total }\end{array}$ \\
\hline 1. & $\left(\mathrm{X}_{1}\right) \rightarrow(\mathrm{Y})$ & 0,218 & $\left(\mathrm{X}_{1}\right) \rightarrow(\mathrm{Z}) \rightarrow(\mathrm{Y})$ & 0,094800 & 0,312800 \\
2. & $\left(\mathrm{X}_{2}\right) \rightarrow(\mathrm{Y})$ & 0,413 & $\left(\mathrm{X}_{2}\right) \rightarrow(\mathrm{Z}) \rightarrow(\mathrm{Y})$ & 0,121344 & 0,534344 \\
3. & $\left(\mathrm{X}_{3}\right) \rightarrow(\mathrm{Y})$ & 0,148 & $\left(\mathrm{X}_{3}\right) \rightarrow(\mathrm{Z}) \rightarrow(\mathrm{Y})$ & 0,020619 & 0,168619 \\
4. & $(\mathrm{Z}) \rightarrow(\mathrm{Y})$ & 0,237 & & & \\
\hline
\end{tabular}

Sumber: data diolah

Berdasarkan pada perhitungan di atas, variabel independen yang mempunyai pengaruh paling kuat terhadap Kepuasan Kerja (Z) adalah Iklim Organisasi $\left(X_{2}\right)$ yaitu sebesar 0,512 . Iklim Organisasi $\left(X_{2}\right)$ juga merupakan variabel yang mempunyai pengaruh paling kuat terhadap Turnover Intention $(\mathrm{Y})$ yaitu sebesar 0,413 . Dengan demikian variabel independen yang mempunyai pengaruh paling kuat terhadap Turnover Intention ( $\mathrm{Y}$ ) melalui variabel intervening Kepuasan Kerja (Z) adalah juga Iklim Organisasi $\left(X_{2}\right)$ sebesar 0,534344 . Sehingga Iklim Organisasi $\left(X_{2}\right)$ merupakan variabel yang paling berpengaruh terhadap Turnover Intention $(\mathrm{Y})$ baik secara langsung maupun dengan melalui Kepuasan Kerja (Z). 


\section{Kesimpulan}

Stress kerja, iklim organisasi dan employee engagement berpengaruh terhadap turnover intention dan juga kepuasan kerja, sedangkan variabel yang paling berpengaruh secara langsung maupun tidak langsung terhadap turnover intention adalah iklim organisasi. Hal ini berarti sebagian besar pegawai Dinas Pendidikan Kabupaten Probolinggo berada dalam kondisi tidak stres, iklim organisasi yang kondusif, employee engagement yang baik, dan pegawai merasa puas dalam bekerja, sehingga dapat menekan angka turnover intention pegawai Dinas Pendidikan Kabupaten Probolinggo.

\section{Saran}

Berdasarkan hasil pembahasan dan kesimpulan, maka dapat diajukan beberapa saran sebagai berikut: (a) meskipun sebagian besar pegawai tidak dalam kondisi stres, namun cukup banyak pegawai yang mengalami stres. Diperlukan upaya-upaya nyata yang berkesinambungan untuk menurunkan tingkat stres pegawai di tempat kerja misalnya dengan, memastikan jumlah pegawai yang cukup untuk menangani berbagai pekerjaan, menjaga hubungan dan pola kerja yang baik antar pegawai, memastikan adanya komunikasi dua arah dan kerjasama yang baik antara bagian dengan pimpinannya, memastikan adanya informasi yang cukup bagi para untuk mendukung penyelesaian pekerjaanya dan upaya-upaya lain yang dapat menekan tingkat stres pegawai; (b) bagi peneliti selanjutnya juga dapat ditambahkan variabel lain yang mempengaruhi, misalnya variabel motivasi kerja, gaya kepemimpinan. 


\section{Daftar Referensi}

Bianca. A, dan Susihono W., 2012, Pengaruh Iklim Organisasi Dan Pengembangan Karir Terhadap Kepuasan Kerja Karyawan. Spektrum Industri,Vol.10,No.2 : hal. 108 199

Fitria, Novy, 2015, Pengaruh Stres Kerja dan Iklim Organisasi terhadap Turnover Intention dengan Kepuasan Kerja sebagai Variabel Intervening pada Perawat RS. X di Surabaya, Jurnal Online - Jurnal Ekonomi Akuntansi dan Manajemen.

Mamewe, Lanny, 2015, Stres Kerja dan Iklim Organisasi serta Pengaruhnya terhadap Turnover Intention dengan Kepuasan Kerja sebagai Variabel Pemediasi, Jurnal Riset Bisnis dan Manajemen Vol 3 ,No.4, 2015: 358-371.

Rachman, Lutfi dan Dewanto, Aryo, 2016, Pengaruh Employee Engagement terhadap Kepuasan Kerja dan Turnover Intention Perawat (Studi pada Rumah Sakit Wava Husada Kepanjen Malang), Jurnal Aplikasi Manajemen (JAM) Vol 14 No 2, 2016

Ridwan dan Kuncoro, Engkos Ahmad.2007. Cara Menggunakan dan Memakai Analisis Jalur (Path Analysis). Alfabeta. Bandung.

Robbins, Stephen P, dan Judge, Timothy A., 2013, Perilaku Organisasi, Salemba Empat, Jakarta.

Schiemann, W. A. 2011. Aligment Capability Engagement. Jakarta: PPM Manajemen

Sugiyono, 2013, Metode Penelitian Kuantitatif Kualitatif dan R\&D, Penerbit Alfabeta, Bandung.

Tadampali, Andi Caezar To dan Hadi, Abdurrahman serta Salam, Rudi, 2016, Pengaruh Iklim Organisasi terhadap Turnover Intention melalui Kepuasan Kerja sebagai Intervening pada PT Bank Sulawesi Tenggara, Jurnal Administrasi Publik, Volume 6 No. 2.

Wirawan, 2007, Budaya dan Perilaku Organisasi, Salemba Empat, Jakarta. 